\title{
The Holy Spirit and The Individual
}

\author{
NeLs F. S. FERRE
}

In our age the individual is the key to a new and better world. This is an age of individualism. The bad part of it is not the individual, but the "ism." For man's history demands that there be ages of individuation, if the fellowship is to be full and free. Thus the dwelling on the values and rights of the individual over and against all collectives, whether controlled by an abusive clique or by a generally in. different majority, has in fact been a most needed condition. But where individuation is good, individualism is bad. for that means that the individual is made an end and a standard over and against society as a whole. Yet such "demonic" excesses are bound to characterize the swinging of the pendulum in this direction and become, unless corrected, which they seldom are by themselves, the occasion for social disintegration or even catastrophe, out of which must then be built a new age, learning from the last, but again tending to react diastrously, either into tameness of life, or into new forms of self-destruction.

This individualism is good or bad to whatever extent the work of the Spirit of God is transferred over to the work of the Holy Spirit. The Spirit of God works to make individuals real and free. From the very beginning of our lives, He makes self-regard the most natural reaction; and to the very end of our lives, except as we are burned out completely in the holy fires of the Holy Spirit and filled with all the fullness of God, He keeps strengthening our self-regard as an accompanying temptation of all our actions, in order that, even as our faithfulness in fellowship is intensito fied, it might also at the same time be eft. larged by means of new degrees of free. of God and the Holy Spirit, toward self dom. All personal individuality this and atyay from himself, bear on the probhuman history, even including our Más-lein of social action?

ter's, is then in the constant dialectic, or 1. The primacy of the individual, in tension, between the Spirit of God and the our stage of history, for social action. The

Holy Spirit. There can, therefore, be no progress in the moral and spiritual life in the sense of automatic accumulation, or of the ridding by the self of old evils, for each moment is a new decision in which one might deny the Lord, and each new gain in the Holy Spirit may encounter a fuller and fiercer work of the Spirit of God, tempting to intensified self-concern. We should never forget that the world, the flesh and the devil have their rightful functions as adversaries within the divine economy. Only as the Holy Spirit becomes increasingly in charge of each individual and of an increasing number of individuals can there be real moral and spiritual progress in any authentic sense; even though the demonic individuation caused by the activity of the Spirit of God, the self burning within, is a step toward the possibilities for a fuller salvation.

The Spirit of God is interested in the individual as such, individuating him for freedom and for real self-being; the Holy Spirit is interested in the individual in so far as he overcomes this isolated stage and becomes a member of the fellowship, or, to use Biblical language, a member of the body of Christ. The Holy Spirit works on the level of redemption, using the incentives of agape, or Christ's kind of concern for others. The solution to our individual and social problems will come only when the eros drives have reached their maximum need for individuation, and accept, through frustration and self-despair, the good news of God's agape in Christ Jesus. How, now, does this analysis of the froly Spirit and the individual with regard to Iit constant conflict between the Spirit 
first obvious observation is that, at our stage of the history of man's consciousness, the individual is most accessible to radical transformation. Any individual within earshot, on the radio, or anyone who reads these words, can become a Moody, who after hearing a preacher say that it yet remained to be seen what God could do with one fully consecrated man, simply went home deciding that he would be that man. We may not be able, directly and immediately, to change the whole world, but we can become changed ourselves, if we trust God enough to take up our prostrated lives and walk in power right through our own problems and with power toward the problems of others. History is made up of individuals. To most people it is not given to be a great sun to the needs of the world. But we can be individual lamp-lights where we live, and if enough shine, the city of man will be full of light. We can, in any case, be a large light under God to our own family, and who knows what God will do through our children, if we say faithfully and constantly with Mary, the mother of Jesus, "Be it to me according to thy word"?

Being thus accessible at the center of world-transformation, we should $\mathrm{take}$ courage from the thought that history is majestically open to great souls. When a Jesus,-or even a Gandhi-appears on the scene of human history, that scene is thereby drastically changed. It may be too much to claim that history is merely the shadow of great men, for that shadow is, of course, composed of living, struggling individuals, who compose the determining power of history, in the sense that what they choose, and what they follow, makes history mostly what it eventually becomes. It is not the generals, in the main, but the soldiers who actually win the battles. But what battles will be fought, and where, depends, perhaps, even for the most part itgent task. We are concerned about a upon the staff of generals rather than up new unity within the church universal, on the soldiers. Without exaggerating, we abont an ecumenical church to match can, at least, say that the main lines of world developments. And that is another history are staked out by the frontiernent task. If the world is to remain a thinkers and by lives who sense most deep- meaningful institution to a wider-looking ly the truth and needs of the actual situa- Cra of people, these things must come, in

tion, and make its inherent choices open and articulate to the general mind. Those choices are always many, and the analysis of the situation depends upon the keenness of mind and depth of heart which are brought to the task. The alert few have always been the awakeners of the many to social responsibility in general, and to specific social tasks. The quality of the task depends upon whether their drive is more partial, that is self-regarding in a personal or in a group sense, or more inclusive of the total good and decisively transcending the actual situation: in other words, whether the choices are mostly in the realm of the Spirit of God or are more motivated by the vision and power of the Holy Spirit.

The importance of the individual for social action today is particularly true because of the fact that we are living in an era of individuation. This era has a background of several centuries. It may spell doom for our civilization, which is the usual result of any relativistic, humanistic individualism. It may, however, be the prelude to "a new middle ages," to use Berdyaev's phrase, or to "the end of the Protestant era" to use Tillich's. History today is threatened with premature collectivism. We are under a constant danger of falling prey to an escapist totalitarianism. With the present stress on individualism, if individuals will concentrate on spiritual and moral individuation with a positive Christian content for others, instead of on material rights and social standing, history can move out of an era of individualism into an era of fuller community, without the forfeiting of the gains of this era of individuation.

As a matter of fact, this seems to be our most urgent task today. We are concerned about the unification of the world 
who alone can establish lasting and satisfactory community. No social action can be constructively significant unless it recognizes that, in history, the primacy of reality and of power belongs to the spiritual realm.

2. The primacy of spiritual reality for social action. The spiritual, in itself, cannot take the place of its created expression. Social action is always, therefore, more than mere spiritual change. But it is, first of all, spiritual change. The deepest, the most powerful reality is the invisible world which is eternal, and which underlies all actualization in time and space. First come men, and not things; first come people, and not external arrangements of political, social, educational, or economic nature; first come the spirits, and then come God's created world and the secondary creations in nature and history by the begotten spirits We are not created, except for our physical life. The deepest in all of us, in all men, is the spirit which some effective form or another. Yet our basic task, today, I repeat, is the salvaging of the good of individualism, the responsible freedom of our individuation. In the East, the individual needs to come to fuller self-consciousness and struggle. $\mathrm{He}$ has not yet, as a whole, gone beyond the confines of traditional faiths, of external authorities of religion, or of family and state loyalties. In the West, our jaded individualism must be prevented from turning into premature and destructive collectivisms by means of the deepening and spiritualizing of individuality. Our problem, as Kierkegaard rightly saw, is -depth of inwardness. In Whitehead's terms, religion can be significantly worldloyalty only when the individual has learned in the depths of self-enjoyment what is the meaning and depth of exist ence, through the testing strains of his own solitariness. No social action can be significant in vision or content until iadividuals have been pressed hard by the Spirit of God into the individuations of responsible freedom and have used this freedom, in depths of inwardness, for the

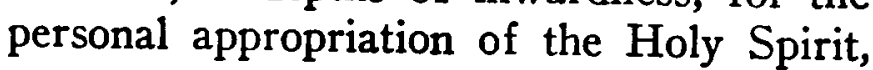

God breathed into us when $\mathrm{He}$ created us in His own image.

However much thwarted and submerged this spirit may be in men, it is, nevertheless, the deepest and most powerful force in their lives. That is why men must rationalize their situation in order to face themselves. That is why they identify themselves with a fictitiously ideal self. That is why most social problems are prefabricated within, and most social reform is merely the rearrangement of externals, in order to fool the self into thinking that he is actually repenting and reforming.

That is also the reason that we fail when we speak in merely external terms, whether in action or in speech. We succeed permanently to change things at their hidden depths only when we speak in the Spirit, in the depth logos which interprets all tongues into its own common language of God's purpose for us all. Here is an understanding that goes deeper than any conscious transmission or any merely human reason or conscience. Here is the court of final appeal. And that is as broad as any truth. We tend to forget, as Bonaventure wrote, "how wide the road of illumination is, and how in each thing, which is sensed or known, God himself lies hidden therein." All depth social action, that will cure the roots of our trouble, and all positive social action, that will release the creativity of authentic vitality, come from the Spirit. That is why such action must be in the Christian dimension of social action.

For the Holy Spirit is the deeper reality of the Spirit of God. The Spirit of God is God working incognito, for our sake, on levels lower than His true self. Yet $\mathrm{He}$ is precisely therefore the key of transmutation. When we work in the Holy Spirit, for and with the secular world, we appeal to the Spirit of God in men rather than to their mere reason, experience, or adyantage. The Holy Spirit has fearful power to stir up those who reject Him, but also wondrous power to set going new and healing streams of social action. A great soul once pointed out the "connatur- 
ality of Spirit in the Saints that will work by sympathy .... as a Lodestone will exercise its attractive Force through a Stone Wall." That connaturality also exists generally because of what Fox called "the Spirit that is in every man," but the lock will not turn and the door will not open until the attractive force of the lodestone has penetrated the wall between the children by creation and the children by adoption. Here is no hiding the differences between them, but here is also no denying the fact of common origin, destiny and sustaining reality within us all. Nor is this analysis based upon a self-sufficient, autonomous man, for whether as the Spirit of God or as the Holy Spirit, the Spirit "in man is just as objective to man as was the historic Christ." ${ }^{2}$ The appeal is, consequently, not to any innate goodness as man's possession, but to the ever operating grace of creation, the prevenient grace that is found throughout all the stretches of history according to previous acceptance and general social circumstance, including the patterns of inherited grace, as a prevenient force, pulsing through family and group life.

Social action must, then, be in the Spirit to be truly constructive and effective. The Spirit is a universal beyond man, but nevertheless $\mathrm{He}$ becomes effective in fellowship through concrete individuals. For the highest spirituality, therefore, we need the highest form of individuality. Toynbee concludes that whether in growth or disintegration it "is equally true that the source of action is never the society itself, but is always some individual soul, that the action which is an act of creation is always performed by a soul which is in some sense a superhuman genius; that the genius expresses himself, like every soul, through action upon his fellows, that in any society the creative personaliti ithough individuals and groups who lay lways in the minority." ". always in the minority." On the other 111 if hand, "the schism in the Human Body So $^{-}$etration below their conscious deliberation. cial .... is an experience which is collective and therefore superficial. Its signif-

icance lies in its being the outward and visible sign of an inward spiritual rift."” An outstanding professor of economics has claimed that "in the realities of life ... progress in the improvement of the legal and traditional order comes about largely through non-conformity and disobedience by individuals who have come to 'higher' standards." All this is true because only spiritual individuals can become the channels concretely for the entrance of the universal, the Spirit, which in one form or the other is common and effective in all. This being so, in a less cynical way perhaps, is it not constructively true, that the priest, as Voltaire sniffed, is a better and far cheaper policeman that the gendarme! If only the priests were good enough, and the people good enough to follow, there would be no need for any policemen!

History, then, depends upon faith, creative vision, and the right relation to the Eternal. Social action depends upon the entrance into history of the Spirit, mostly, as yet, of the Spirit of God, but most effectively and powerfully upon those who live in the Holy Spirit. It is both true that "the possibility of effective democratic society depends on the capacity of men at large to agree upon superindividual norms for the guidance of action in and by groups," and that "confusion regarding ideals is one of the most serious sources of difficulty in the modern social problem." This condition can be remedied only by a new inbreaking of creative truth, and by the motivating power to make that truth contagious and convincing. This cannot be done through pressure groups that cause all other groups to become more and more defensive. This can be done only through super-pressure groups, or

\section{$-$} VII. T., Vol. V, p. 376

\footnotetext{
${ }^{1}$ Nuttall, The Holy Spirit, p. 143. and Religion, p. 83.

${ }^{2}$ Conner, Revelation and God, p. 286 .

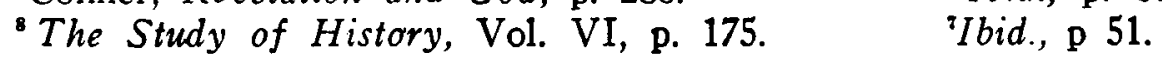


Not collectivized coercion, not organized force, but spiritual power is the main flow of all historic activity: Without its being right, political action will, to that extent, fail of constructive solution.

It is true that "never must the greater community take over the ends and functions of the smaller community;" "that democracy must be made stronger in its patterns, atmosphere, techniques, and especially in group dynamics;"' that "modern society has tended to destroy the intermediary and subsidiary communities through which the individual develops responsibility and mature character."10 But what many recommenders of social action leave out is the fact that what is most needed are individuals of vital personal experience, individuals who let the Spirit come into history, for $\mathrm{He}$ waits human response and participation, being a fellowship Spirit that respects our freedom. What we need are prayer groups, not nurturing neurotically their own insecurity by ritualistic prayers, whether formal or spontaneous, but groups that care for the community and the world, with all their problems, but who care in the Spirit. What is needed is a Spirit-filled Church as the Fellowship of the Concerned. This is the most basic presupposition for creative and constructive social action.

Farmer is indeed right in his claim that in our thought of revelation "the thought of God's personal activity is often not present, or if present, is so much in an attentuated form that the word discovery would be just as appropriate." " The key to social power constructively is God's work in history, when we sufficiently trust and obey Him. Nuttall significantly reminds us that "it" was the church-meeting which gave birth in England, to political democracy, not vice-versa." Micklem's reminder that "all political oriestions are at bottom theological. . that every political system rests upon... the value and meaning of human life;", that "a civilization may be judged by that in it which is accounted sacred." ${ }^{14}$ When this perspective is restored, we shall understand the primacy of the spiritual which becomes historically concrete only through individuals, in proportion to their understanding and acceptance of the Christian dimension of social action, which is the part and power of the Holy Spirit in history, God's concern completely for each and for all, and that within our concrete setting of natural and historical conditions.

3. The involvements and limits of the individual's responsibility. The setting of natural and historical conditions brings up the whole question of social relativism. The question of how any individual can go from self-love, as dominant, to Godlove and other-love, as dominant, is hard enough, but even if one could and should have such a high love, would he not, nevertheless, at the same time participate in the sins of society, and thus forfeit his creative power as an agent for its transformation?

First, then, a word on the former question. It is possible to pass from self-love to God-love and other-love, as dominant, only because individuation is part of a temporary process rather than a permanent status. What we are actually, we are not essentially. Our deepest nature is from God, and for God, and no earthly temptation can destroy that fact. To destroy that fact is to destroy man. Or put it this way, which is even more basic: the work of the Spirit of God and of the Holy Spirit is eventually for the same purpose, and nothing can permanently thwart that which God has purposed. Thus the transition is basically, not man's work, but man's response, and that he can thus reGspond depends upon the fact that his deepest self, most inwardly and basically, wants fori its permanent and total satisfaction the sove of God and the love of others in Bommen, The State in Catholic Thought 15. the Foly Spirit. Self-realization is, most "Muelder. "Concerning Power", Phil. Forum-_ceeply, the realization of God's purpose ${ }_{10}$ Ibid. p. 3.

"The World and God, p. 82 OT TO BE USED WITHOUT COPYATCHT PERMISSION

${ }^{2} \mathrm{Op}$. cit., p. 58.

Of ASBury theologicAMGieklemay The Theology of Politics, p. 38 
dominantly self-willed, but no more can we deny that he is actually miserable about this fact, dissatisfied, tense, defensive. Nor must we overlook the fact that the transition from self-love to other-love involves the shifting of balances on a scale where there are always weights on both sides.

Now to our main question: how can an individual participate in a sinful society, without partaking of its sin, and in so doing, becoming generally as impotent as that sinful society? First, social participation is in grace, but never in sin. There is no social sin and no social guilt. There are social consequences of sin, even as there are social consequences of redemptive activity, but $\sin$ is ever an individual category. Before God, each one must stand alone as a sinner. Sin is what separates; grace is what binds together. In history man shares responsibility and consequences, but morally he is not held responsible for more than his opportunity of effective decision.

We are, however, responsible for the full extent of our delegated power. Each person has power according to his individual ability, application, and concrete circumstance. This responsibility covers both action and non-action. We are responsible for what we do and for what we fail to do. are responsible for everything equally. There has been a good deal of confusion on this subject. There are common areas where, if possible, all ought to participate. All, for instance, should vote. All should attend divine worship. All should share of their income. But this does not mean tion. If a convinced pacifist may use a military figure, we might say that a gen-
This does not mean, however, that we that there are not differentiations of func-

not do all the calling and practical deeds of helpfulness of the pastor. The worker with college youth confesses that he is ashamed of being so little of an evangelist and the evangelist comes around to apologize because he is not enough of an educator. All this is good as a corrective conscience, but a teacher should be a teacher; a man of practical affairs, a man of practical affairs; an evangelist, an evangelist; and a pastor, a pastor. Our consciences trouble us and we are sore afraid because we cannot be perfectly everything, but such a conscience, to a large extent, is the self's attempt to be perfect in itself, rather than to do one's limited duty humbly, as an unprofitable servant, in grace and thanksgiving, realizing one's sins and limitations, and one's powerlessness except for the work of the Spirit of God and of the Holy Spirit in one's life.

It is also well to remember that we are not the Lord of history. God is. That means we are not responsible for the consequences of our deeds, only for the intention, the faith, and the wisdom, through God, of our deeds. Judas might never have hanged himself if Jesus had avoided the Cross. Yet Jesus was not responsible for Judas' betrayal and suicide. Judas was. Neither was Jesus responsible for Peter's betrayal and restoration to leadership. Peter was. Jesus was responsible, under God, for his own acts and words and prayers with regard to both Judas and Peter. If this were not the case, there would be no freedom of genuine worth.

Jesus was not responsible for nor can he be said to have sanctioned war because his tribute money went to support the Roman legions. Neither did he become involved in Herod's grafts and intrigues because his living and working was a positive part of Herod's reign. We are not responsible for cannot dig ditches and the soldier nieed whether our efforts will help friend or foe, have no conscience because he does not provided that we have, honestly and intelknow all the intricacies of military strategy. ligently, made the basic choice as to There are times and places for all things. whether or not our act will be under and Often practical pastors are frustrated be- for God. Political decisions or victories yond effective action, because they can are of an ephemeral nature in comparison not do all the reading of $a_{T}$ Professor the professor is frustrated, because Bher can-ocGod'sumark in history. That does not reg- 
ister flood or ebb according to our human circumstance of relative political good.

If we could only keep this firmly in mind! We are not the Lords of history whether of our own group locally, nationally, or internationally. God and only God is the Lord of history. Our job, therefore, is not to control the totality of history. Our job is, rather, to be faithful at our post and to our duty as prescribed by His Word, by the enactment in human history of His eternal love.

This, however, is but the negative side of the picture. We have stressed it because many are either deceived honestly, or else hide behind the idea that since sin infects the totality of human history, and since we are part of that history and cannot avoid $\sin$, we might as well sin that grace might abound. Participation in the least possible choice has thus become an evasion of responsible non-conformity. The fact that the world is sinful is no reason why I have to commit adultery. The fact that the world is sinful is no reason why $I$ have to steal, tell lies, or be ungenerous. All this is an excuse. The fact that the world is sinful is, similarly, no reason by itself, for instance, why I have to participate in war. The perversions of a rightful function and the destructive use of a constructive institution have, in no way, the same claim on me as the proper function or the constructive claim of the institution.

But positively, the individual introduces constructive and healing vision and energy into history, when his life is lived dominantly in the power of the Holy Spirit. Here is no human perfectionism, claiming power individually to withstand the massive powers of institutional evil. Here is no individual isolationism, where the individual is kept free and clean from social defilements. Here is, rather, the claim that the social nature and power of the spirit of God, of the Holy Spirit, and, especially, of the co-working of the two in tension and co-operation, can enter into individuals both on the level of creation and on th level of redemption, producing both the ideals of right and the empowereds
Bangor said: God can work "speaking through the sanctified common sense of persons whose lives are full of the fruits of the Spirit."

The Christian is not very much interested in limiting his responsibility, but very eager to enlarge it through the power of God to the fullest use to which God wants to put him, whether through conformity or through non-conformity. The Christian is not much concerned about being free from guilt, but is, rather, interested in being "made sin" for the world, that through him, God's forgiving and healing power may flow into the world. The Christian dimension on social action is the perspective of God's perfection taking hold of the individual, more and more, and working through him for fuller and freer fellowship, for a new and better people, for a new and better social order. Naturally, the full, historic key to this is the Christian Church, for that is the only incarnation in history of the Holy Spirit. Our supreme loyalty, in history, must always be to the unbroken Christian fellowship. Our stress, in this particular analysis, however, is on each person, because it is often forgotten that here is the concrete reality of which even the Christian fellowship must be composed.

All of history can be radically changed through us, if we have the faith to believe and to obey God. We live, as Toynbee writes, in a "generation which has been born into the critical act of the tragic

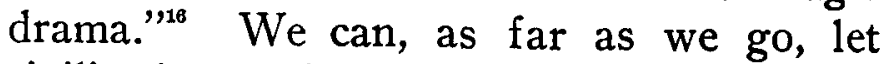
civilization perish. We can become defeatists or escapists. We can also, however, become those who are completely used by God in daily surrender. We can consecrate both mind and heart to our tasks of staggering human proportions, and yet very ismall in comparison to God's immeasurable power. We can remember that Christendom is no mere dream but practical politics if its cause be served by those who add to a sound philosophy by a passionate faith."

Micklem, op. cit., p. 160. 